\title{
FRICTION STIR PROCESSING OF ALUMINUM FUSION WELDS
}

\author{
Christian Fuller, Murray Mahoney, and William Bingel \\ Rockwell Scientific \\ 1049 Camino Dos Rios \\ Thousand Oaks, CA 91360
}

\begin{abstract}
Friction stir processing (FSP) is used to modify the microstructure and the resultant properties of fusion welded aluminum alloys. Non-heat treatable $5083-\mathrm{H} 321 \mathrm{Al}$ is subjected to FSP at the fusion weld toe, crown, and heat-affected zone locations. FSP affects both the local fusion weld microstructure and residual stresses. To understand the influence of FSP on fusion welds, the effect of different FSP processing approaches is investigated. The morphology and spatial distribution of precipitates and grains are examined through optical microscopy, scanning electron microscopy, and transmission electron microscopy. The relationships between microstructure and properties such as strength and ductility are discussed. Consideration is given to the local properties in transition regions between the different microstructures, i.e., fine grain FSP zone, cast fusion zone, and parent metal.
\end{abstract}

\section{INTRODUCTION}

Friction stir processing (FSP) produces local thermomechanical deformation to improve the local microstructural properties of cast and wrought alloys. The basic concepts of FSP are the same as those of friction stir welding (FSW) [1]. However, in FSP no joining of plates is performed. Instead, the FSP tool is rastered across the desired region of the work piece to create a fully recrystallized, porosity-free, finegrained microstructure.

The utility of FSP was recently demonstrated with several alloy systems. A finegrained microstructure produced alloys capable of high strain-rate superplasticity, 5 $\mathrm{mm} 7075 \mathrm{Al}$ [2], and thick section bending, $25 \mathrm{~mm} 2519 \mathrm{Al}$ [3]. A combination of grain refinement and porosity healing has lead to an improvement in the mechanical properties of cast $304 \mathrm{Al}$, NiAl bronze, and Mg-Cu alloys [4-6]. In addition, FSP has improved the mechanical properties of fusion welded iron base alloys [7]. The tools utilized in FSP share the same basic concepts as FSW tools, but FSP tools are designed for specific applications and work piece geometries.

FSP of Al fusion welds are a demonstration of the utility of FSP for innovative structural enhancement. Fusion welds have long been noted to be the weakest locations within structures, and FSP should improve the microstructural and mechanical properties of Al fusion welds. This manuscript reports an initial investigation of FSP modification of $\mathrm{Al}$ fusion welds. Research to establish the optimal combination of tool design and tool parameters for fusion welded 5083-H321 is in progress. 


\section{Report Documentation Page}

Form Approved

OMB No. 0704-0188

Public reporting burden for the collection of information is estimated to average 1 hour per response, including the time for reviewing instructions, searching existing data sources, gathering and maintaining the data needed, and completing and reviewing the collection of information. Send comments regarding this burden estimate or any other aspect of this collection of information,

including suggestions for reducing this burden, to Washington Headquarters Services, Directorate for Information Operations and Reports, 1215 Jefferson Davis Highway, Suite 1204, Arlington

VA 22202-4302. Respondents should be aware that notwithstanding any other provision of law, no person shall be subject to a penalty for failing to comply with a collection of information if it

does not display a currently valid OMB control number.

\begin{tabular}{|c|c|c|}
\hline $\begin{array}{l}\text { 1. REPORT DATE } \\
\mathbf{2 0 0 6}\end{array}$ & $\begin{array}{l}\text { 2. REPORT TYPE } \\
\text { N/A }\end{array}$ & $\begin{array}{l}\text { 3. DATES COVERED } \\
\text { - }\end{array}$ \\
\hline \multirow{3}{*}{\multicolumn{2}{|c|}{$\begin{array}{l}\text { 4. TITLE AND SUBTITLE } \\
\text { Friction Stir Processing Of Aluminum Fusion Welds }\end{array}$}} & 5a. CONTRACT NUMBER \\
\hline & & 5b. GRANT NUMBER \\
\hline & & 5c. PROGRAM ELEMENT NUMBER \\
\hline \multirow{3}{*}{\multicolumn{2}{|c|}{ 6. AUTHOR(S) }} & 5d. PROJECT NUMBER \\
\hline & & 5e. TASK NUMBER \\
\hline & & 5f. WORK UNIT NUMBER \\
\hline \multicolumn{2}{|c|}{$\begin{array}{l}\text { 7. } P E R F O R M I N G \text { ORGANIZATION NAME(S) AND ADDRESS(ES) } \\
\text { Rockwell Scientific } 1049 \text { Camino Dos Rios Thousand Oaks, CA } 91360\end{array}$} & $\begin{array}{l}\text { 8. PERFORMING ORGANIZATION } \\
\text { REPORT NUMBER }\end{array}$ \\
\hline \multirow{2}{*}{\multicolumn{2}{|c|}{ 9. SPONSORING/MONITORING AGENCY NAME(S) AND ADDRESS(ES) }} & 10. SPONSOR/MONITOR'S ACRONYM(S) \\
\hline & & $\begin{array}{l}\text { 11. SPONSOR/MONITOR'S REPORT } \\
\text { NUMBER(S) }\end{array}$ \\
\hline
\end{tabular}

12. DISTRIBUTION/AVAILABILITY STATEMENT

Approved for public release, distribution unlimited

13. SUPPLEMENTARY NOTES

The original document contains color images.

14. ABSTRACT

15. SUBJECT TERMS

16. SECURITY CLASSIFICATION OF:

a. REPORT

unclassified b. ABSTRACT

unclassified c. THIS PAGE

unclassified
17. LIMITATION OF ABSTRACT

$\mathbf{U U}$
18. NUMBER 19 a. NAME OF

OF PAGES RESPONSIBLE PERSON

9 


\section{EXPERIMENTAL PROCEDURES}

Table 1 contains the chemical composition (in wt.\%) of the investigated 5083-H321 $\mathrm{Al}$ alloy as reported by the alloy manufacturer. Automated metal inert gas (MIG) welding of $6 \mathrm{~mm}$ thick 5083-H321 Al was performed parallel to the longitudinal direction of the rolled plates (5356 Al filler alloy). FSP utilized two different tools: a tool with a small diameter shoulder and a customized pin and a tool with a larger diameter scrolled shoulder and the same shape of customized pin with a shorter length. Currently, the exact design and operating parameters of the tools are propriety. The small diameter shoulder tool was designed for FSP of the fusion weld toes, while the larger diameter scrolled shoulder tool was designed for FSP of the entire fusion weld crown. FSP was performed with the FSP tool operating in Z-axis load control. In this study, four FSP conditions are examined: as-fusion welded, small shoulder tool with the fusion weld on the advancing side of the FSP tool, small shoulder tool with the fusion weld on the retreating side of the FSP tool, and large shoulder tool.

Microstructural observations were made with optical, scanning electron (SEM), and transmission electron microscopies (TEM). Samples for optical microscopy and SEM were sectioned perpendicular to the direction of welding (short-transverse direction). The samples were polished with $\mathrm{SiC}$ paper and alumina slurries to a surface finish of $0.05 \mu \mathrm{m}$, and electrolytically etched with Barker's solution (5 vol.\% fluoroboric acid in water). TEM specimens were electropolished with a solution of $33 \mathrm{vol}$. \% nitric acid in methanol at $-25^{\circ} \mathrm{C}$. Samples for TEM were observed in a Philips CM-30 TEM operating at $300 \mathrm{kV}$.

Tensile and fatigue samples were machined perpendicular to the fusion weld direction. Tensile bars had a gauge diameter of $4 \mathrm{~mm}$, and the reported tensile properties are the average for three samples. Surface residual stresses were measured by X-ray diffraction (XRD), Lambda Research (Cincinnati, Ohio USA), employing a $\sin ^{2} \Psi$ technique in accordance with ASTM E1426.

Table 1: Composition of 5083-H321 Al (wt. \%).

\begin{tabular}{|c|c|c|c|c|c|c|c|c|c|}
\hline $\mathrm{Mg}$ & $\mathrm{Mn}$ & $\mathrm{Si}$ & $\mathrm{Fe}$ & $\mathrm{Zn}$ & $\mathrm{Ti}$ & $\mathrm{Cu}$ & $\mathrm{Cr}$ & Others & $\mathrm{Al}$ \\
\hline 4.7 & 0.5 & 0.11 & 0.29 & 0.08 & 0.01 & 0.05 & 0.08 & 0.15 & Balance \\
\hline
\end{tabular}

\section{RESULTS AND DISCUSSION}

\section{$\underline{\text { Microstructure }}$}

Figure 1 (a-d) is a collection of optical macrographs taken in the short-transverse direction (perpendicular to the fusion weld) for the four FSP conditions: (a) as welded; (b) small shoulder tool with fusion weld on advancing side; (c) small shoulder tool with fusion weld on retreating side; and (d) large shoulder tool. The FSP tool travel direction is into the page, and the advancing side of the tool is on the right-hand side (counter-clockwise tool rotation). Indicated in Fig. 1 are the three microstructural regions observed in this study: fusion weld, parent material (PM), and fine-grain FSP, as indicated by 1, 2, or 3, respectively. 


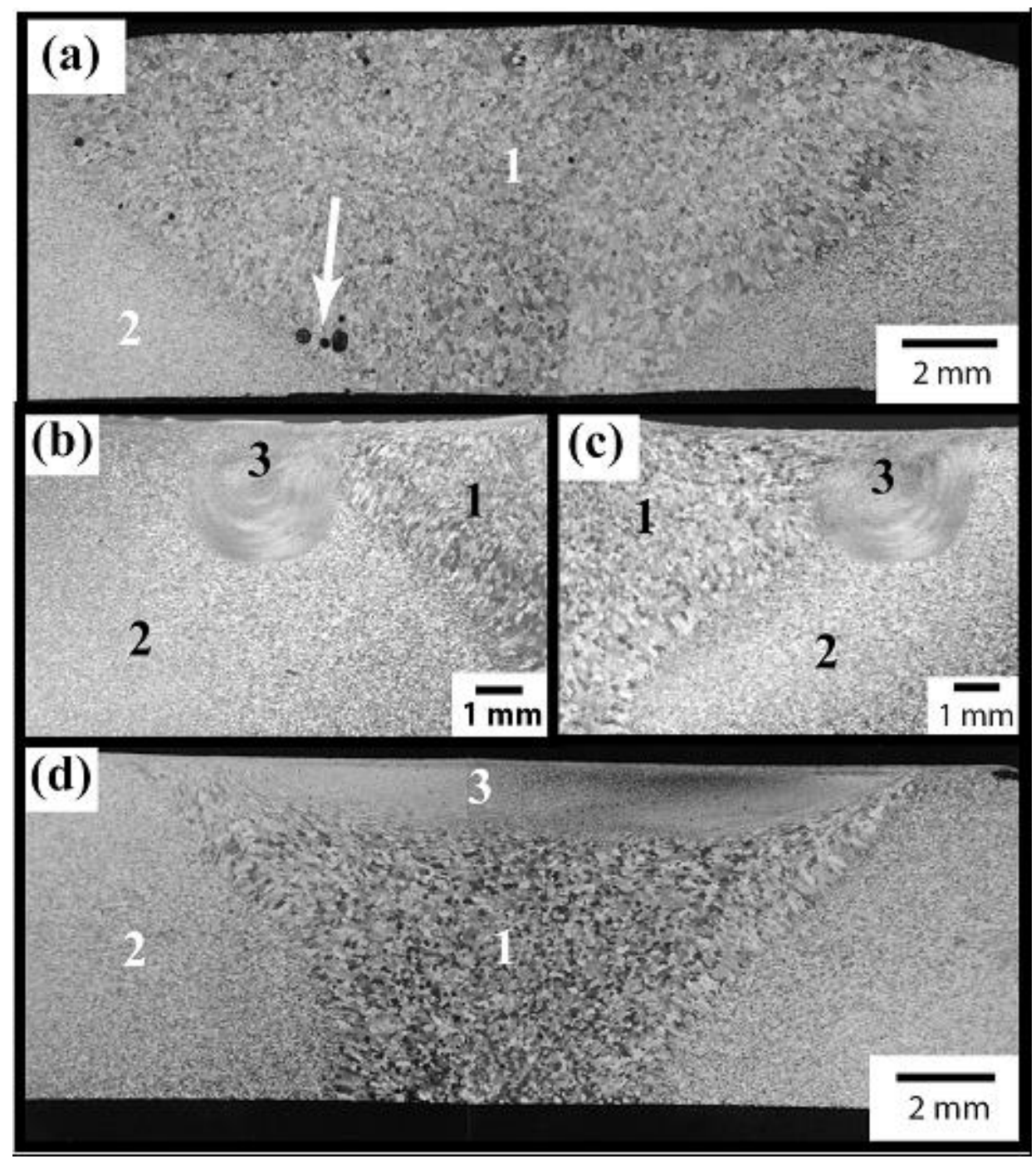

Figure 1: Optical macrographs of 5083-H321 Al in the following conditions: a) asfusion welded; (b) small shoulder tool with fusion weld on advancing side; (c) small shoulder tool with fusion weld on retreating side; and (d) large shoulder tool. Different microstructural regions within the micrographs are indicated by: 1 fusion weld (5356 Al); 2 parent material (5083 Al); and 3 fine-grain FSP. The arrow in (a) indicates porosity within the fusion weld. The right hand side is the advancing side of the FSP tool, and the direction of tool travel is into the page.

The fusion weld region has a course-gain microstructure comparable to that of a cast alloy. As seen in cast microstructures, porosity is present in the fusion weld, arrow in Fig. 1 (a). Grains in the PM exhibit the typical elongated structure of rolled plate material. The fine equiaxed grains observed in the FSP region are the result of mixing both the fusion weld and PM alloys. Intimate mixing of the fusion weld metal (5356 $\mathrm{Al}$ ) with the parent metal (5083-T321 Al) is observed for all FSP conditions, Figs. 1 (b-d). Significant differences in the profiles of the small shoulder tool as a function of fusion weld location (advancing side vs. retreating side) are not observed with optical microscopy. The small shoulder tool also produces the commonly observed "onion ring" structure, Figs. 1(b) and (c). However, the "onion ring” structure is not observed with the large shoulder tool, Fig. 1(d), due to the design of the scrolled shoulder and customized pin. The alternating dark and light layering found in bi-alloy 
FSW [8] is not observed. This can be attributed to the similar compositions of the PM (5083) and filler (5356) alloys, which cause both alloys to etch at similar contrast levels.

SEM was utilized to examine the larger diameter precipitates $(>1 \mu \mathrm{m})$, which appeared in two types of phases. One precipitate phase contained $\mathrm{Al}, \mathrm{Mn}$, and $\mathrm{Fe}$, which (in $5083 \mathrm{Al}$ ) has been suggested to be $\mathrm{Al}_{6}(\mathrm{Fe}, \mathrm{Mn})$ [9-11]. The second precipitate phase contained $\mathrm{Mg}$ and $\mathrm{Si}$, and is most likely $\mathrm{Mg}_{2} \mathrm{Si}$ [12]. The solvus temperatures of $\mathrm{Al}_{6}(\mathrm{Fe}, \mathrm{Mn})$ and $\mathrm{Mg}_{2} \mathrm{Si}$ are reported to be around $635^{\circ} \mathrm{C}$ [11], and $637^{\circ} \mathrm{C}$ [13], respectively. Both of these temperatures are higher than the solvus of $5083\left(575^{\circ} \mathrm{C}[11]\right)$, so the precipitates will not completely dissolve until the alloy melts. TEM was utilized to examine the smaller diameter precipitates $(<1 \mu \mathrm{m})$. As observed in the SEM, TEM observations show two precipitate phases: large $\mathrm{Mg}_{2} \mathrm{Si}$ and fine $\mathrm{Al}_{6}(\mathrm{Fe}, \mathrm{Mn})$. Table 2 compares the precipitate phases found by the two microscopic techniques as a function of microstructural region within the small shoulder tool with the fusion weld on the advancing side. The $\mathrm{Mg}_{2} \mathrm{Si}$ phase found by both SEM and TEM were of the same approximate area; while the $\mathrm{Al}_{6}(\mathrm{Fe}, \mathrm{Mn})$ phase consisted of a bimodal distribution of precipitates, one population with diameters $>1$ $\mu \mathrm{m}$ and one population with diameters $<1 \mu \mathrm{m}$. Fine $\mathrm{Al}_{6}(\mathrm{Fe}, \mathrm{Mn})$ precipitates were not found within the fusion weld region, because the precipitates were not kinetically favored to form during the fusion weld solidification. The presence of the fine $\mathrm{Al}_{6}(\mathrm{Fe}, \mathrm{Mn})$ precipitates in the $\mathrm{PM}$ can be attributed to the thermomechanical processes encountered during plate formation. Because of their small size, the $\mathrm{Al}_{6}(\mathrm{Fe}$, $\mathrm{Mn})$ precipitates are expected to be quite effective in pinning dislocations, so the effect of FSP on the fine $\mathrm{Al}_{6}(\mathrm{Fe}, \mathrm{Mn})$ precipitates is discussed below. To date, the $\beta$ phase $\left(\mathrm{Al}_{3} \mathrm{Mg}_{2}\right.$, solvus of $450^{\circ} \mathrm{C}$ [14]) has not been found in the alloys investigated in this research. The low solvus temperature indicates that formation of the $\beta$ phase is thermodynamically favored, but the work piece does not maintain a precipitation temperature for a sufficient period of time.

Table 2: Precipitate phases (as found by the indicated observational technique) as a function of microstructural region within the small shoulder tool with the fusion weld on the advancing side.

\begin{tabular}{|c|c|c|c|}
\hline & PM & Fusion Weld & FSP \\
\hline \multirow{2}{*}{ SEM } & $\begin{array}{c}\mathrm{Al}_{6}(\mathrm{Fe}, \mathrm{Mn}) \\
\mathrm{Mg}_{2} \mathrm{Si}\end{array}$ & $\begin{array}{c}\mathrm{Al}_{6}(\mathrm{Fe}, \mathrm{Mn}) \\
\mathrm{Mg}_{2} \mathrm{Si}\end{array}$ & $\begin{array}{c}\mathrm{Al}_{6}(\mathrm{Fe}, \mathrm{Mn}) \\
\mathrm{Mg}_{2} \mathrm{Si}\end{array}$ \\
\hline \multirow{2}{*}{$\mathrm{TEM}$} & $\begin{array}{c}\mathrm{Al}_{6}(\mathrm{Fe}, \mathrm{Mn}) \\
\mathrm{Mg} \mathrm{Si}_{2} \mathrm{Si}\end{array}$ & $\mathrm{Mg}_{2} \mathrm{Si}$ & $\begin{array}{c}\mathrm{Al}_{6}(\mathrm{Fe}, \mathrm{Mn}) \\
\mathrm{Mg}_{2} \mathrm{Si}\end{array}$ \\
\hline
\end{tabular}

Figure 2 consists of two bright-field TEM micrographs illustrating the morphology and spatial distribution of the fine $\mathrm{Al}_{6}(\mathrm{Fe}, \mathrm{Mn})$ precipitates found in the FSP regions of the (a) small shoulder tool with the fusion weld on the advancing side and (b) large shoulder tool. Both TEM micrographs exhibit small grains containing either high or low dislocation densities, the microstructure expected for recrystallized grains. The fine $\mathrm{Al}_{6}(\mathrm{Fe}, \mathrm{Mn})$ precipitates produced by the small shoulder tool, Fig. 2(a), occur in rod and spheroidal morphologies, while the fine $\mathrm{Al}_{6}(\mathrm{Fe}, \mathrm{Mn})$ precipitates produced by the large shoulder tool have primarily spheroidal morphologies. TEM tilting experiments determined that the rod and spheroidal precipitates are two distinct morphologies, and are not the result of plate precipitates with changing orientations. 


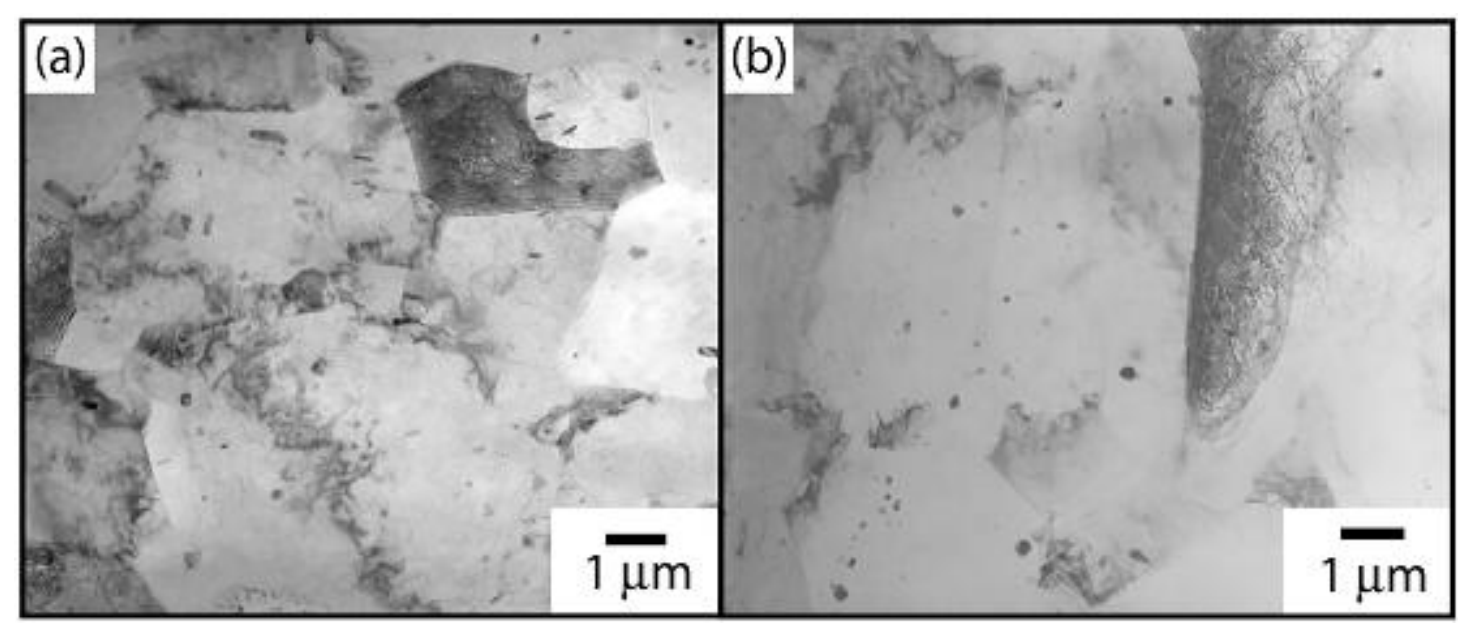

Figure 2: Bright-field TEM micrographs of the FSP region of (a) small shoulder tool with fusion weld on the advancing side and (b) large shoulder tool.

To quantify the differences in precipitate morphologies, TEM images were used to determine the average projected area and aspect ratio of $\mathrm{Al}_{6}(\mathrm{Fe}, \mathrm{Mn})$ precipitates (Table 3) contained within the FSP region. The $\mathrm{Al}_{6}(\mathrm{Fe}, \mathrm{Mn})$ precipitates in the small shoulder tool FSP region are observed to have a larger average projected area, 32900 $\pm 1500 \mathrm{~nm}^{2}$, Fig. 2 (b), than those seen in the large shoulder tool, $8700 \pm 700 \mathrm{~nm}^{2}$, Fig. 2(a). In addition, the precipitates observed after FSP with the small shoulder tool were more elongated (average aspect ratio of $1.70 \pm 0.04$ ), than precipitates deformed by the large shoulder tool (average aspect ratio of $1.26 \pm 0.02$ ), Table 3 .

Table 3: Characteristics of $\mathrm{Al}_{6}(\mathrm{Fe}, \mathrm{Mn})$ precipitates as reported from TEM observations.

\begin{tabular}{|c|c|c|}
\hline Tools & $\begin{array}{c}\text { Average Projected } \\
\text { Precipitate Area }\left(\mathrm{nm}^{2}\right)\end{array}$ & $\begin{array}{c}\text { Average Aspect } \\
\text { Ratio (max./min) }\end{array}$ \\
\hline Small shoulder tool & $32900 \pm 1500$ & $1.70 \pm 0.04$ \\
\hline Large shoulder tool & $8700 \pm 700$ & $1.26 \pm 0.02$ \\
\hline
\end{tabular}

Figure 3 contains the precipitate size distributions (PSDs) in the form of histograms of the normalized precipitate area (area/ average area, $\mathrm{a} /<\mathrm{a}>$ ). It is apparent from the PSDs that both of the FSP regions have a wide distribution of precipitate sizes. However, the large shoulder tool produces a PSD with a narrower peak than the small shoulder tool. This indicates that the large shoulder tool has a tighter distribution of precipitate sizes than the small shoulder tool.

The FSP region of the small shoulder tool is due to the rotation of the pin, while the FSP region of the large shoulder tool is influenced by the shoulder rotation. TEM observations indicate that the large shoulder tool is more effective in decreasing the average precipitate area than the small shoulder tool. As reported above, the solvus temperature of $\mathrm{Al}_{6}(\mathrm{Fe}, \mathrm{Mn})$ is above the solvus temperature of $5083 \mathrm{Al}$. A decrease in the precipitate size due to heating alone would require the dissolution of precipitates, which occurs upon alloy melting. The thermal influence of FSP causes the existing $\mathrm{Al}_{6}(\mathrm{Fe}, \mathrm{Mn})$ precipitates to coarsen, and nucleates new precipitates (if there is sufficient solute supersaturation in the matrix). Therefore, other factors must be involved. Most likely the increased material deformation (pin vs. scrolled 
shoulder) would break-up the precipitates, causing a decrease in the average projected precipitate area.

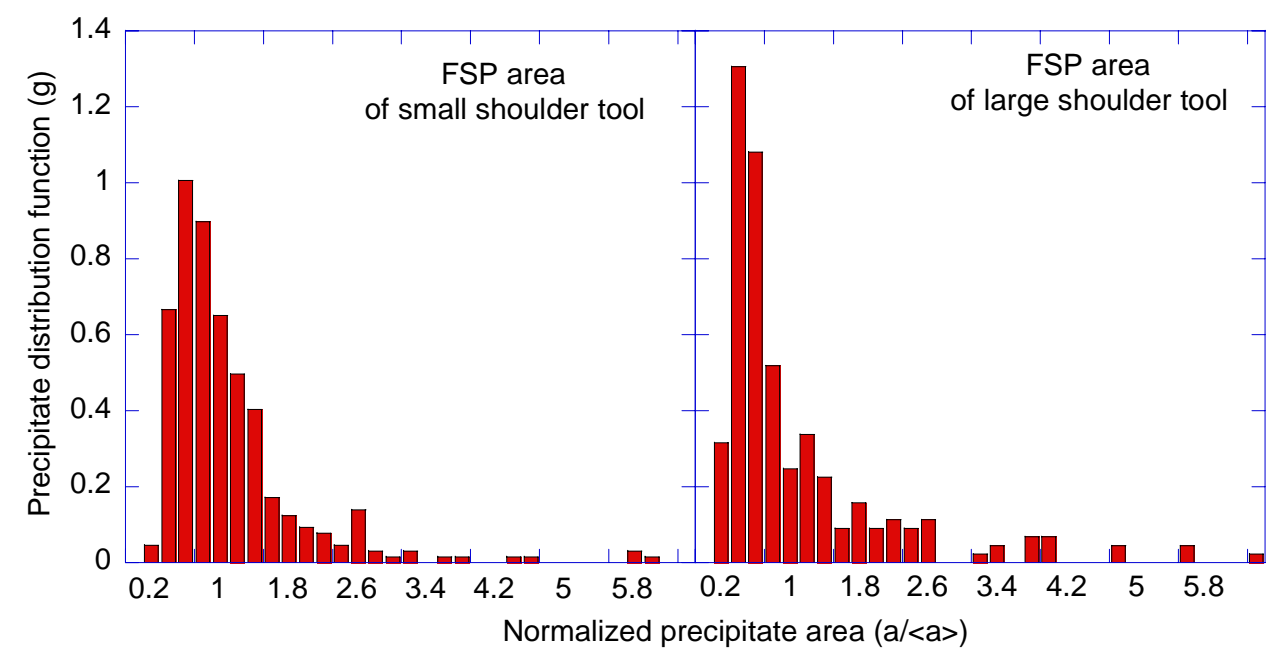

Figure 3: $\mathrm{Al}_{6}(\mathrm{Fe}, \mathrm{Mn})$ precipitate size distributions (PSDs), in which histograms of the distribution function, g, are plotted as a function of normalized area, $\mathrm{a} /<\mathrm{a}>$. These distributions are for the precipitates located within the FSP region of the small shoulder tool with the fusion weld on the advancing side and the large shoulder tool.

\section{$\underline{\text { Tensile Properties }}$}

Table 4 tabulates the tensile property results as a function of sample condition for FSP modified 5083-H321 Al fusion welds. Machining $1 \mathrm{~mm}$ from the top and bottom surfaces of the plate produced the tensile bars. Therefore, the tensile properties reflect the interior influence of FSP, and not the surface layer FSP deformation. The yield strength is observed to increase with the addition of FSP, to a maximum level of $19 \%$ (compared to the as-fusion welded condition). Both conditions for the small shoulder tool are observed to have higher yield strengths than the large shoulder tool. Tensile strength is reported to range from 270 to $280 \mathrm{MPa}$, and no change is observed with the addition of FSP (outside of sample error). Sample elongation is high ( $>23 \%$ ) for all of the sample conditions. Fracture surface examination of the tensile samples indicates that some porosity may be present. However, the pullout of large precipitates complicates determination of the percentage of porosity.

All of the specimens failed in the center of the fusion weld, away from where FSP occurred. Optical microscopy of the failure regions did not indicate that FSP produced a variation in the grain size. Therefore, the differences in yield strength are either due to the formation of fine precipitate phases and dislocation networks, or data scatter. TEM samples of the failure regions of the as-welded and small shoulder tool with the fusion weld on the retreating side were examined. Due to the thermomechanical deformation, both samples had a high density of dislocation networks and subgrain boundaries. Diffraction pattern analysis indicated the presence of a precipitate phase within the FSP sample. However, the fine phase cannot be distinguished from the dislocation network structure. A possible reason for this is that the precipitates are too small to be observed with conventional TEM. The fine 
precipitate phase is formed from the radiant heat produced during FSP, and confirmation of the presence of the precipitates is ongoing.

Table 4: Average tensile properties of friction stir processed 5083-H321 Al fusion welds.

\begin{tabular}{|c|c|c|c|}
\hline Sample condition & $\begin{array}{c}\text { Yield Strength } \\
\text { (MPa) }\end{array}$ & $\begin{array}{c}\text { Tensile Strength } \\
(\mathrm{MPa})\end{array}$ & $\begin{array}{c}\text { Elongation } \\
(\%)\end{array}$ \\
\hline As-fusion welded & $115 \pm 2$ & $273 \pm 2$ & $23.2 \pm 3.9$ \\
\hline $\begin{array}{c}\text { Small shoulder tool with } \\
\text { fusion weld on advancing side }\end{array}$ & $131 \pm 2$ & $270 \pm 8$ & $23.7 \pm 1.5$ \\
\hline $\begin{array}{c}\text { Small shoulder tool with } \\
\text { fusion weld on retreating side }\end{array}$ & $137 \pm 2$ & $277 \pm 3$ & $24.3 \pm 0.5$ \\
\hline Large shoulder tool & $124 \pm 4$ & $272 \pm 5$ & $28.6 \pm 1.5$ \\
\hline
\end{tabular}

\section{$\underline{\text { Residual stresses }}$}

Residual stress measurements from the weld crown surface for two FSP conditions (as-fusion welded and FSP with a large shoulder tool) are shown in Fig. 4 where: (a) are the x-ray measurements conducted parallel to the fusion weld and (b) are the x-ray measurements conducted perpendicular to the fusion weld. Examination of Figure 4 (a) indicates several trends about the residual stresses measured parallel to the fusion weld. FSP with the large shoulder tool produces tensile residual stresses ( $20-50$ $\mathrm{MPa}$ ) near the tool shoulder diameter, $\pm 15 \mathrm{~mm}$ from the weld centerline. Residual stresses increase in compressive nature (maximum value of -140 to - $160 \mathrm{MPa}$ ) as the distance from weld centerline is increased. The highest compressive stress for the FSP plate ( $\pm 50 \mathrm{~mm}$ from the weld centerline) is due to the forces applied by the clamping needed for FSP. The as-welded material has tensile residual stresses ( 6 to $25 \mathrm{MPa}$ ) at $\pm 5 \mathrm{~mm}$ from the weld centerline, and compressive stresses ( -50 to -90 $\mathrm{MPa})$ for the remainder of the plate.

The perpendicular measurements, Fig. 4 (b), show the FSP modified fusion weld to exhibit a majority of compressive residual stresses (-25 to $-70 \mathrm{MPa}$ ), with a single tensile stress (28 MPa) $12 \mathrm{~mm}$ from the weld centerline. The as-fusion welded plate also has a majority of compressive residual stresses, but with a higher magnitude (-10 to $-100 \mathrm{MPa}$ ) than observed from the FSP modified fusion weld. Tensile residual stresses observed for the FSP modification of the fusion welded corresponds to the edge of the FSP tool. Within the fusion weld area $( \pm 25 \mathrm{~mm})$, the FSP modified fusion weld has higher tensile stresses (parallel to the fusion weld) and compressive stresses (perpendicular to the fusion weld) than the as-welded case. This residual stress distribution indicates that an increase in fatigue life threshold should occur in the FSP material, as was previously shown by adding residual stresses to the weld 
section of FSW 7050-T7651 Al [15].

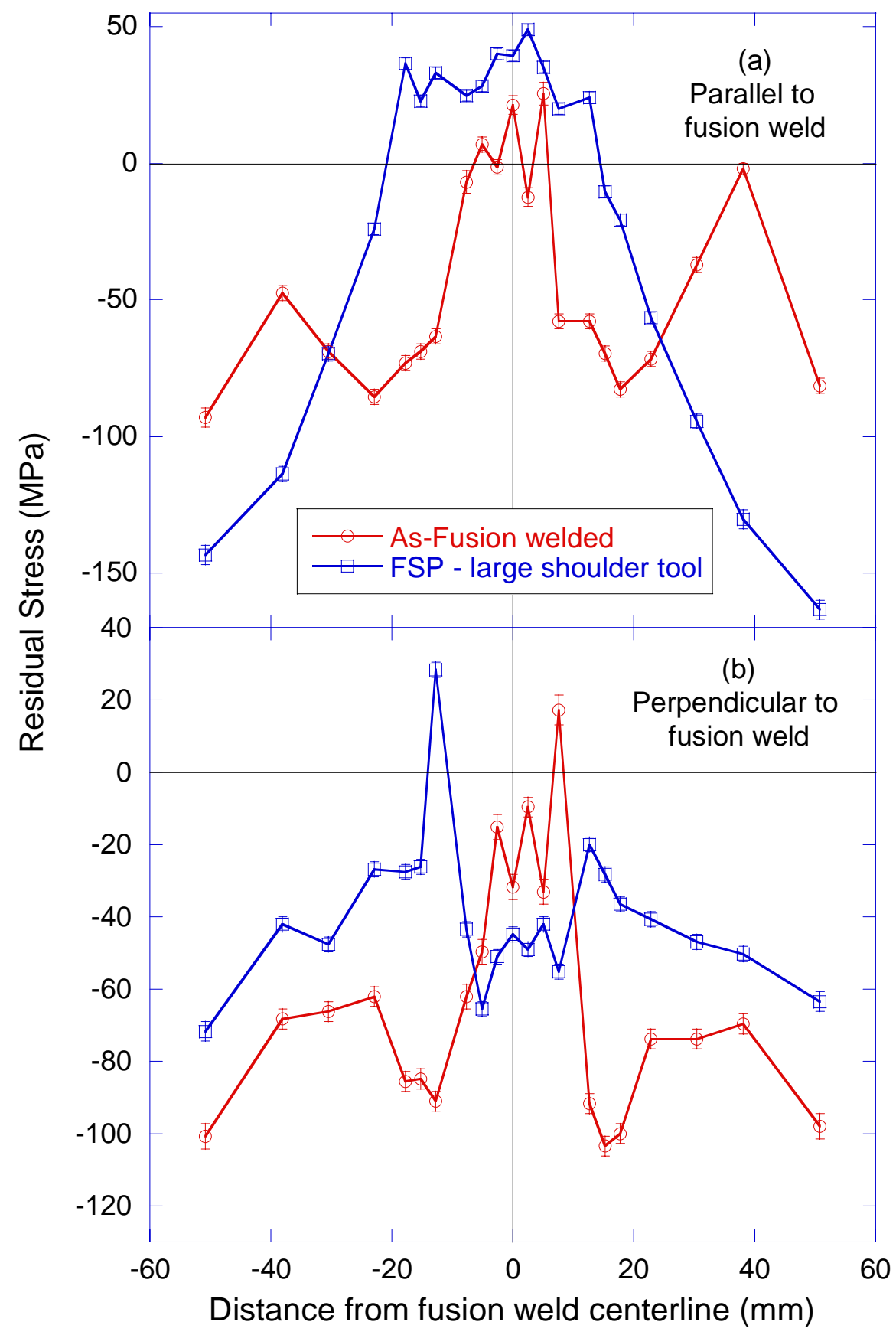

Figure 4: $\quad$ Residual stress measurements taken with the x-ray oriented (a) parallel to the fusion weld and (b) perpendicular to the fusion weld.

\section{CONCLUSIONS}

This work has demonstrated that FSP can produce an improvement in the microstructural and mechanical properties of fusion welded 5083-H321 Al. The 
effect of the parent material, fusion weld, and FSP regions on the mechanical properties has been presented and discussed. A comparison was produced to determine the effectiveness of two FSP locations (fusion weld toe vs. fusion weld crown) utilizing two different tool designs (small shoulder tool vs. large scrolled shoulder tool). FSP of the fusion weld toe produced higher yield strength, while FSP of the fusion weld crown was more effective in breaking up $\mathrm{Al}_{6}(\mathrm{Fe}, \mathrm{Mn})$ precipitates.

\section{ACKNOWLEDGEMENTS}

The authors would like to thank the financial support of the Defense Advanced Research Projects Agency (DARPA), under contract No. MDA972-02-C-0300, and Dr. Leo Christodoulou, Program Manager, and NSWC Carderock Division as Program Monitor.

\section{REFERENCES}

[1] W.M. Thomas, E.D. Nicholas, J.C. Needham, M.G. Murch, P. Templesmith, and C.J. Dawes, G.B. Patent No. 9125978.8, U.S. Patent No. 5460317.

[2] M. Mahoney, R.S. Mishra, T. Nelson, J. Flintoff, R. Islamgaliev, and Y. Hovansky, Friction Stir Welding and Processing, TMS Indianapolis, IN, 2001, 183-94.

[3] M.P. Miles, M.W. Mahoney, T.W. Nelson, and R.S.Mishra, Friction Stir Welding and Processing II, TMS San Diego, CA, 2003.

[4] Z.Y. Ma, S.A. Shaarma, R.S. Mishra, and M.W. Mahoney, Thermec 2003, Madrid, Spain, 2003.

[5] S.P. Lynch, D.P. Edwards, A. Majumdar, S. Moutsos, and M.W. Mahoney, Thermec 2003, Madrid, Spain, 2003.

[6] M.W. Mahoney, W.H. Bingel, R.S. Mishra, Thermec 2003, Madrid, Spain, 2003.

[7] C.J. Sterling, T.W. Nelson, C.D. Sorensen and M. Posada, Thermec 2003, Madrid, Spain, 2003.

[8] H. Larsson, L. Karlsson, S. Stoltz,. E.-L. Bergqvist, Proceedings of the $2^{\text {nd }}$ International Symposium on Friction Stir Welding, Sweden, August, 2000.

[9] K. Kannan, C.H. Hohnson, and C.H. Hamilton, Metall. Mater. Trans. A, 1998, 29A, 1211-20.

[10] H.B. McShane, C.P. Lee, and T. Sheppard, Mater. Sci. Technol., 1990, 6, 42840.

[11] Y.S. Sato, S.H.C. Park, and H. Kokawa, Metall. Mater. Trans. A. 2001, 32A, 3033-42.

[12] L.F. Mondolfo, Aluminum Alloys: Structure and Properties, Butterworths, London, 1976, 808.

[13] A.A. Nayeb-Hashemi and J.B. Clark, in Binary Alloy Phase Diagrams Vol. 2, Eds. T. B. Massalaski, J.L. Murray, L.H. Bennett, H. Baker, ASM Int., Metals Park, OH, 1986, 1544-45.

[14] J.L. Murray, in Binary Alloy Phase Diagrams Vol. 1, Eds. T. B. Massalaski, J.L. Murray, L.H. Bennett, H. Baker, ASM Int., Metals Park, OH, 1986, 12931.

[15] N. Jayaraman, P.S. Prevey, M.W. Mahoney, Friction Stir Welding and Processing II, TMS, San Diego, CA, 2003. 